\title{
ボールミル処理により形成した非晶質米粉の吸湿性の低下
}

\author{
安斎真由美 ${ }^{1}$, 深見 健 $^{2}$, 渡辺 学 ${ }^{1}$, 鈴木 徹 ${ }^{1, \dagger}$ \\ ${ }^{1}$ 東京海洋大学, ${ }^{2}$ サンエイ糖化株式会社
}

\section{Reduction of Moisture Absorption of Amorphous Rice Flour Formed by Ball Milling}

\author{
Mayumi ANZAI ${ }^{1}$, Ken FUKAMI ${ }^{2}$, Manabu WATANABE ${ }^{1}$, Toru SUZUKI ${ }^{1, \dagger}$ \\ ${ }^{1}$ Tokyo University of Marine Science and Technology, 4-5-7 Konan, Minato-ku, Tokyo 108-8477, Japan \\ ${ }^{2}$ SAN-EI Sucrochemical Co., Ltd., 24-5 Kitahama-cho, Thita-shi, Aichi-ken 478-8503, Japan
}

\begin{abstract}
This study reports on the reduction of moisture absorption of amorphous rice flour formed by ball milling. Ball milling has been applied to starch for conversion of its physico-chemical properties. Ball milling converts the semi-crystalline state of starch to an amorphous state, and the prolonged procedure promotes enthalpy relaxation. It has been reported that prolonged treatment leads to an decrease in starch water sorption. However, because the size of the ball mill container was small in a previous study, it was not suited for industrial applications. In the present study, a vibrated type ball milling with a large container of rice was carried out for up to $9 \mathrm{hr}$. The confirmation of crystalline was evaluated by using the X-ray diffractometry. The relaxed enthalpy $(\Delta H)$ was measured by differential scanning calorimetry. Water sorption isotherms were measured by equilibrium sorption of water vapor. With the milling time, enthalpy relaxation was found to increase and water sorption to decrease. The sorption isotherms were analyzed with a dual mode sorption model, and the concentration, $C_{H}{ }_{H}$, of Langmuir type sorption site was found to decrease with the time. In the present study, the ball milling was to improve the adsorption properties of rice flour, that regardless of the size of the ball mill container, it has been found that it is possible to create an amorphous rice flour with physicochemical properties.
\end{abstract}

Keywords: rice flour, ball milling, amorphous, enthalpy relaxation, moisture absorption

1. 緒言

米は，世界で最も重要な食用作物の1つである [1]. 食糧自給率が年々減少している我が国で米だけは $100 \%$ の自給率を維持できてはいるものの一人当たりの米の 消費量は年々低下して打り，ピーク時の半分にまで低 下している [2]，そこで，多くの機関においては，国産 米の消費拡大を推進する取組みが行われてきているが, 粒食としての米の消費には限界があるため, 粉食とし ての米の利用について広く検討が行われている [3].

米粉は，澱粉粒が複粒を形成しているため粉砕が難 しく，従来に打いては上新粉，白玉粉，打よび餅粉な どが存在するのみだったが，これらの米粉は粒子が粗 いため, 団子，柏餅などの和菓子や米菓などの原料と

(受付 2013 年 12 月 27 日, 受理 2014 年 7 月 23 日)

1 ₹ 108-8477 東京都港区港南 4-5-7

2 个478-8503 愛知県知多市北浜町 24-5

Fax: 03-5463-0585, E-mail: toru@kaiyodai.ac.jp
しての利用が主であった [4]。 そこで，粒度分布を小麦 粉に近づけ，小麦粉の代替として使用できる米粉が求 められている [2]. しかしながら，米粉やその主成分で ある澱粉は, 米粉の加熱・糊化処理時の物性制御が難 しく, 調理加工適性が小麦粉と比較して劣る [5]. また, 米粉を用いた食品は，加熱・糊化処理により急激に粘 度が増加するため，糊のような重いテクスチャを有す るなど食品加工原料としての利用範囲が限定されてき た [6].

米粉の物理化学的特性の改善法として, 高圧处理 [7], 温水処理 [8,9], 湿熱处理 $[10,11]$ ，マイクロ波加熱処理 [12,13], 加熱・せん断処理 [14] などの様々な処理法が 有効であることが先行研究により報告されている。物 理的処理方法により作成された米粉は，製造工程にお いて化学物質が添加されることがないことから, 安全 性の面からもとても利点がある [6]. また，物理的处理 法によって改質された米粉の物理化学的特性について も，米粉の粉砕方法 [15] 打よび米粉パン，米粉麺や米 
パスタなどの米加工品の加工適性に関する報告が先行 研究により報告されている [16-18].

一方，材料工学分野では，古くからボールミル処理 が粉体の改質方法として知られてきた。ボールミル処 理は, 円筒形の容器に原料と多数の硬球を入れ回転さ せることで, 球の落下と摩擦で試料を粉砕する処理方 法である. Yamada らは，小型の回転ボールミル処理機 を用いて処理した澱粉の X 線回折測定から，未処理澱 粉に観察される結晶性に帰属する回折強度が，処理時 間の延長に従って減少することを報告している [19]. Kim らは，小型ボールミル処理が馬鈴著澱粉を非晶質 状態へと変化させ，エンタルピー緩和を促進させたと 報告している [20]. 非晶質状態にある物質において, ガラス転移温度 $T_{g}$ 以下では分子主鎖のミクロブラウン 運動は凍結されているが，局所的運動は凍結されてい ないため，穴のため $T_{g}$ 以下に扎いてもごく近傍にある 分子間あるいは分子内の相互作用で可能な配置をとり ながらできる限りエネルギー的に安定な方向へと変化 する。この現象を構造緩和もしくはエンタルピー緩和 と呼ぶ。つまり，ボールミル処理による衝撃によりエ ンタルピー緩和が促進されることから，エネルギー的 により安定な状態にある非晶質澱粉の作成を可能とし たことを意味している，また，馬鈴薯澱粉のボールミ ル处理によりエンタルピー緩和が進行した結果，水分 収着性が低下するという報告もある $[21,22]$. 彼らは工 ンタルピー緩和と水分収着性は相関する関係にあると 推測しており，ボールミル処理によって非晶化された 澱粉は吸湿特性が低下するため, その加工特性も変化 することが予想される。

これまでの先行研究においては，澱粉の非晶質化ま でにおよそ 20 時間を要しており, 容器の大きさも小さ かったことから実生産には向かなかった。矢のため, 実用化のためには，処理量の大きな装置で米粉の粉砕 を行う必要があったが，処理量の大きな装置で米粉の 粉砕を行ううえで, 先行研究で報告されてきた小型ボー ルミル処理機により得られたエンタルピー緩和の進行 や水分収着性の低下などの物理化学的特性が同様に得 られるのかは不確かであった。

そこで，本研究では，非晶化された澱粉を含み，効 率的な米の粉砕を可能とする, 先行研究よりも处理量 の大きなボールミル装置を用いて米粉を作成し, 結晶 性，エンタルピー緩和および水分収着量の各測定から その物理化学特性を評価することを目的とした。

\section{2. 実験試料および実験方法}

\section{1 実験試料}

実験には，平成 19 年産の福島県産コシヒカリ (精米 歩留まり約 $91.6 \%$ ）を用いた。

\section{2 ボールミル処理}

ボールミル处理には，振動型ボールミル機 (MB-1, 中央化工機株式会社）を用いた。直径 $14 \mathrm{~cm}$ ，高さ 24 $\mathrm{cm}$ の円筒容器（ステンレス製）に，直径 $1.4 \mathrm{~cm}$ の金 属球（ステンレス製） $384 \mathrm{~g}$ と米 $208 \mathrm{~g}$ を入れ，室温， 振動数 $880 \mathrm{rpm}$ で $0 ， 3 ， 6 ， 9$ 時間ボールミル処理を施 し米粉を作成した。 また，ボールミル処理で作成した 米粉と比較するため, 小型粉砕機（WB-1, 大阪ケミカ ル株式会社）を用いて米粉を作成した。これ以降，小 型粉砕機で作成した米粉を未処理米粉，ボールミル機 で作成した米粉をボールミル処理米粉と定義する.

また，未処理米粉とボールミル処理米粉の水分含量 を加熱乾燥法 $\left(105^{\circ} \mathrm{C} ， 24\right.$ 時間) により測定した [23]. 得られた水分含量は，未処理米粉で $17.7 \%$ ，ボールミ 儿処理 3，6，9 時間でそれぞれ $18.6 \% ， 18.3 \% ， お よ$ び $17.7 \%$ でっっ.

\section{3 広角 $\mathrm{X}$ 線回折測定}

広角 X 線回折装置（MiniFlex II，株式会社リガク） を用い, X 線管球 : $\mathrm{CuK} \alpha$, 電圧 $: 30 \mathrm{kV}$, 電流 $: 20 \mathrm{~mA}$, 走查速度 : $2^{\circ} / \mathrm{min}$, 走査範囲 : $2 \theta=4 \sim 40^{\circ}$ の条件下で $\mathrm{X}$ 線回折パターンを求め $[22,24]$, 未处理米粉打よびボー ルミル処理米粉の結晶構造の変化を評価した.

\subsection{DSC 測定}

未処理米粉打よびボールミル処理米粉約 $25 \mathrm{mg}$ を而 圧製アルミニウムパン (外形 $\phi 7 \mathrm{~mm} \times 5 \mathrm{~mm}$ : 株式会社島 津製作所）に詰め，試料を金属棒でプレスしてから， 水分の蒸発を防ぐため蓋をして圧着器具（SSC-30，株 式会社島津製作所）によって密封した，基準物質には アルミナを用いた。キャリブレーションにあたっては, インジゥム (融点, $156.6^{\circ} \mathrm{C}, \Delta H_{m}, 28.5 \mathrm{~J} / \mathrm{g}$ ) と蒸留水 (融点， $0.0^{\circ} \mathrm{C}, \Delta H_{m}, 333 \mathrm{~J} / \mathrm{g}$ ) を用いた。

示差走查熱量計（DSC-50，株式会社島津製作所）炉 体外側の容器に液体窒素を入れ, 昇温速度 $: 5^{\circ} \mathrm{C} / \mathrm{min}$, 昇温範囲：-10 $180^{\circ} \mathrm{C}$ の条件下で測定を行った $[22$, 24]. 各試料は最低 3 つの試料を測定し，測定より得ら れた $T_{g}$ 打よびエンタルピー緩和量 $(\Delta H)$ の平均値を それぞれ各試料の $T_{g}$ 打よび $\Delta H$ とした。 また，測定に より得られた $T_{g}$ および $\Delta H$ の解析には, 解析用ソフト ウェア（TA-60WS，株式会社島津製作所）を用いた。

\section{5 水分収着量の測定}

水分収着量の測定は，安斎らの方法を用いて行った $[22,24]$. 水分活性測定器（柴田科学株式会社）の内室に 未処理米粉打よびボールミル処理米粉を静置し，外室 にはそれぞれ水分活性 $\left(a_{w}\right)$ の異なる 8 種類の塩 $\left(a_{w}\right.$ : 0.082 0.753）を入れ，塩が溶けない程度の蒸留水をた らして飽和状態とし, 水分活性測定器の本体と蓋にワ 
セリンを塗り密閉した。 これを， $25^{\circ} \mathrm{C}$ の恒温器で重量 変化がなくなるまで約 7〜8 時間程度静置した後，試料 の重量を計り，放置後の水分含量を以下の式 (1)-(3)を 用いて算出した。

$$
\begin{gathered}
\left(D_{1}\right) \times\left(P_{0}\right)=W_{0} \\
\left(W_{0}\right)+\left(D_{2}\right)=W_{1} \\
{\left[\left(W_{1}\right) /\left\{\left(D_{1}\right)-\left(W_{0}\right)\right\}\right] \times 100=P_{1}}
\end{gathered}
$$

ここで， $D_{1}(\mathrm{~g})$ は，水分収着前の試料重量， $P_{0}(\%)$ は, 初期水分含量の割合, $W_{0}(\mathrm{~g})$ は, 水分収着前の水分含量, $D_{2}(\mathrm{~g})$ は，水分収着後の試料重量増減， $W_{1}(\mathrm{~g})$ は，水 分収着後の水分含量, $P_{1}(\%)$ は，水分収着後の水分含 量を表す.

\section{3. 結果と考察}

\section{1 米粉の結晶性の変化}

Fig. 1 に，未処理米粉打よびボールミル処理米粉 (3, 6，9 時間）の広角 X 線回折図を示す.未処理米粉の回 折曲線は，穀物澱粉に特有の $\mathrm{A}$ 形の結晶形を示した。 一方で，ボールミル処理米粉の回折曲線は，ボールミ ル処理時間が増加するにつれて結晶性に起因するピー クが消失する傾向を示し，ボールミル処理 9 時間の米 粉では，ほぼ完全に非晶質状態になったと判断された。 本研究におけるボールミル処理と規模は異なるが，先 行研究の馬鈴著澱粉と同様の結果を得ており [20，21], 小麦澱粉においても一定時間以上ボールミル処理を行 うことにより，内部構造が完全に非晶質状態へと変化 することが報告されている [25-27]. しかしながら，先 行研究の小型ボールミル機では，澱粉がほぼ完全に非 晶質化するのに执よそ 17 時間を要していた [20]. 本研 究では，処理能力の高い大きなボールミル機を用いる

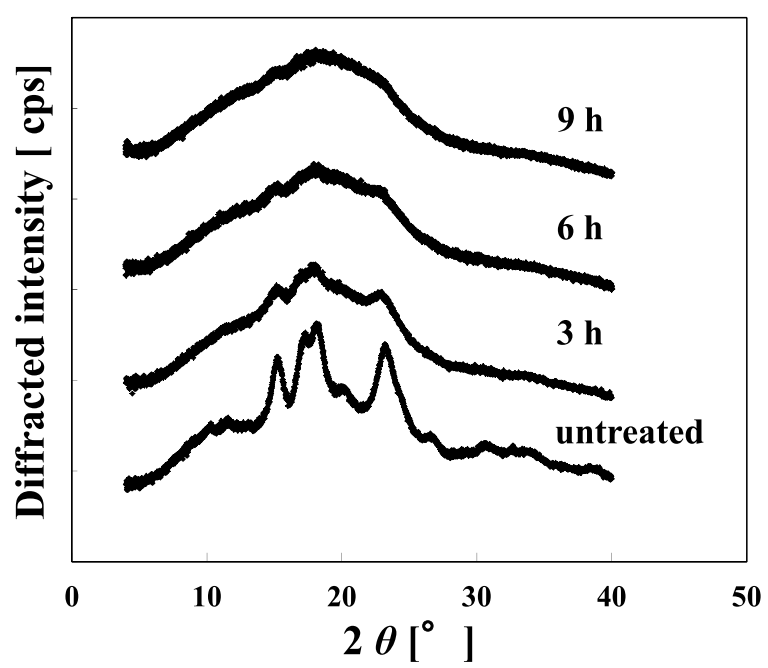

Fig. 1 X-ray diffraction patterns of the untreated rice flour and ball milled rice flour.
ことで処理時間を短縮できた。また，Hoseneyらは， 室温で澱粉のボールミル処理を行い，複屈折打よびX 線回折曲線の結果から澱粉の結晶構造の崩壊が起きて いること，つまり，澱粉の非晶質化が起きていること を報告している [28]. Morrison らは，ボールミル処理 に伴い小麦澱粉のアミロース含量は変化しないが，結 晶化度の減少と同時に低分子量のアミロペクチンが増 加すると報告している $[25 ， 26]$. 澱粉において，アミ ロペクチン側鎖の非還元末端の直鎖部分が二重螺旋構 造を形成することが知られているが $[22 ， 29]$ ，これら の螺旋構造は水素結合を介して平行に配列されている [30]. これが澱粉の結晶形成の基礎となるといわれて いるが，非晶質化による結晶構造の完全な破壊は，螺 旋の結晶配列が崩壊するために起きると推測される [22]. そして，その効果は，結果としてアミロペクチ ン鎖に打ける極性水酸基の増加をもたらすとの報告も ある [31]. したがって，澱粉の物理的な非晶質化は， 新しく水素結合を形成する澱粉の基本的な結晶構造の 崩壊を可能とし [32]，このような再形成過程が澱粉を 非晶質状態へと恋化させると考えられる [33].

一方，米は，澱粉のほかに蛋白質など多くの成分も 多く含んでいる。蛋白質は，米の細胞壁や澱粉粒の表 面を覆っているため，米粉のボールミル処理による米 粉の粉砕に伴う蛋白質やその他成分の影響についても 検討する必要があると考えられるが，本研究において は，蛋白質や他の成分の影響については検討しなかっ たためここでは議論しないこととする.

\section{2 米粉のエンタルピー緩和 $(\Delta H)$ の変化}

Fig. 2 に，未処理米粉打よびボールミル処理米粉 (3, 6, 9 時間）の DSC 曲線を示す．未処理米粉の DSC 曲 線に打いて，約 $60^{\circ} \mathrm{C}$ 付近に吸熱ピークが観察された. Thiewes \& Steeneken は，水分含量 $16 \%$ の未処理澱粉 で DSC 測定を行い, $60^{\circ} \mathrm{C}$ 付近の吸熱ピークを” $\mathrm{sub}-T_{g}$ endotherm”と定義している。彼らは，この吸熱ピー クを澱粉の単離，貯蔵により起こる未処理澱粉の非晶 質部におけるエンタルピー緩和と関連すると考察して いる [34].

次に，ボールミル処理米粉では，ガラス転移と重な り合う吸熱変化を約 $60^{\circ} \mathrm{C}$ 付近で観察した。この吸熱変 化は，非晶質部分の構造緩和，エンタルピー緩和によ るものと考えられる．Fig. 2 には，DSC 測定より得ら れた米粉のエンタルピー緩和量 $(\Delta H)$ の変化を示すが, 米粉の $\Delta H$ はボールミル処理の進行に伴い増加する傾 向を示したことから，既往の報告例と同様にボールミ ル処理過程がエンタルピー緩和を促進させることを米 粉に扔いても確認できた

ボールミル処理による澱粉のエンタルピー緩和の促 進については，Kim らにより次のような仮説が立てら 


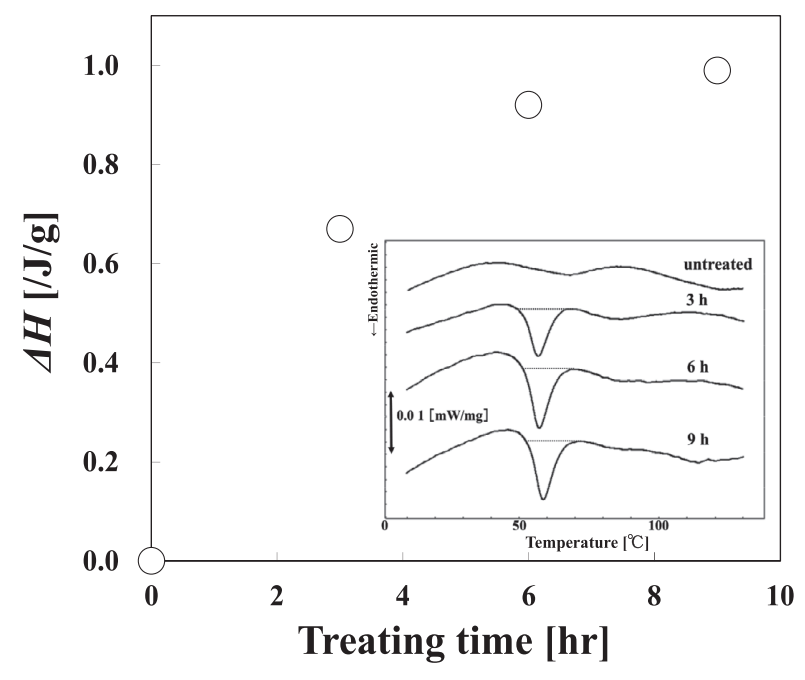

Fig. 2 DSC curves of untreated rice flour and ball-milled rice flour and dependence of $\Delta H$ on ball milling time.

れている [20].

1. ボールミル処理による衝撃は， $T_{g}$ 以下でのエージン グ，アニーリングなどの物理的処理と同様に，澱粉構 成鎖の分子再配列を起こし，活性化エネルギーが吸熱 方向に進行する。

2. ボールミル処理による澱粉分子の脱重合が, エンタ ルピー緩和の促進をもたらす.

ボールミル処理を含む澱粉の機械的処理が，澱粉の 脱重合を起こすという報告はいくつか存在する $[7,27$, 36].これは，澱粉が脱重合により低分子化することに より，エンタルピー緩和速度が速くなると考えられる ため，結果的にエンタルピー緩和が増加すると推測さ れている [22]. 先行研究に打ける結果を支持するなら ば，本研究におけるボールミル処理米粉中の澱粉も低 分子化されているのではないかと推測される.

一方，ボールミル処理 9 時間の米粉では，ボールミ ル処理中の容器内温度の上昇による影響で，澱粉の一 部糊化が起きていないかについて懸念された。しかし ながら, 先行研究により澱粉の糊化を速やかに完了さ せるには，40\%程度の水分が必要であることが報告さ れている [35]. また，実際にボールミル処理後に測定

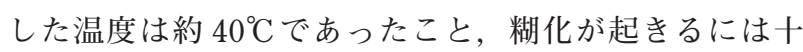
分な水分が存在しないことから，ボールミル処理中に 糊化は起きていないものと考える.

\section{3 米粉の水分収着量の変化}

Fig. 3 には，未処理米粉およびボールミル処理米粉 (3，6，9 時間）の水分収着等温線を示す.未処理米粉 と比較してボールミル処理米粉は，ボールミル処理時 間が増加するにつれて吸湿性が減少する傾向を示した (Fig. 3).

ボールミル処理時間を長く行うことにより，平均粒
子径扎よびその分布も変化すると推測されたが, Strange らは，硬質赤小麦ふすま，燕麦ふすまおよび小 麦ふすまに打いて，粉砕，ふるい分けをして6つの粒 子サイズ画分を調整し，水分吸着指標を測定している が，粒子サイズの減少に伴い硬質赤小麦ふすまの吸着 指標は減少し，また燕麦繊維では増加し，一方，トウ モロコシでは大きな変化がなかったと報告しており [37]，彼らは，粒子サイズと水分収着の間には一般的 な関係を見出すことができなかったと述べている。し たがって，本研究に打いて水分収着量を測定するうえ で米粉の平均粒子径は大きな影響を及ぼさないと仮定 し，平均粒子径の測定は行わないこととした。しかし ながら，米粉の吸湿性を予測するうえで，米粉の平均 粒子径打よびその分布を把握することはとても重要で あることから，実際に確認する必要があると考える. 今後米粉の平均粒子径打よびその分布について検討を 行い，平均粒子径の変化が米粉の吸湿性に及ぼす影響 について確認する予定である.

澱粉は，水分を多く吸着することによって膨潤し， 収着機構が収着量によって変化すると考えられる。本 研究では，その影響を排除するため， $a_{w} \leqq 0.33$ の単分 子収着領域に着目し，安斎らが用いた下記の二元収着 モデル式である式 (4) を用いてより詳細な水分収着の解 析を行った [38].

$$
\frac{1}{C-k_{d} a_{w}}=\frac{1}{C_{H}^{\prime} b}\left[\frac{1}{a_{w}}\right]+\frac{1}{C_{H}^{\prime}}
$$

ここで，C (g/g dry basis)， $a_{w}(-)$ は，それぞれ水分 収着量打よび水分活性であり， $k_{d}(\mathrm{~g} / \mathrm{g})$ は，ヘンリー 定数である。また， $C^{\prime}{ }_{H}(\mathrm{~g} / \mathrm{g}$ dry basis $), b(-)$ は，そ れぞれ単分子層収着が飽和したときの収着量打よび収 着平衡定数である. 式 (4) を用いて, $k_{d}$ の值を変化させ,

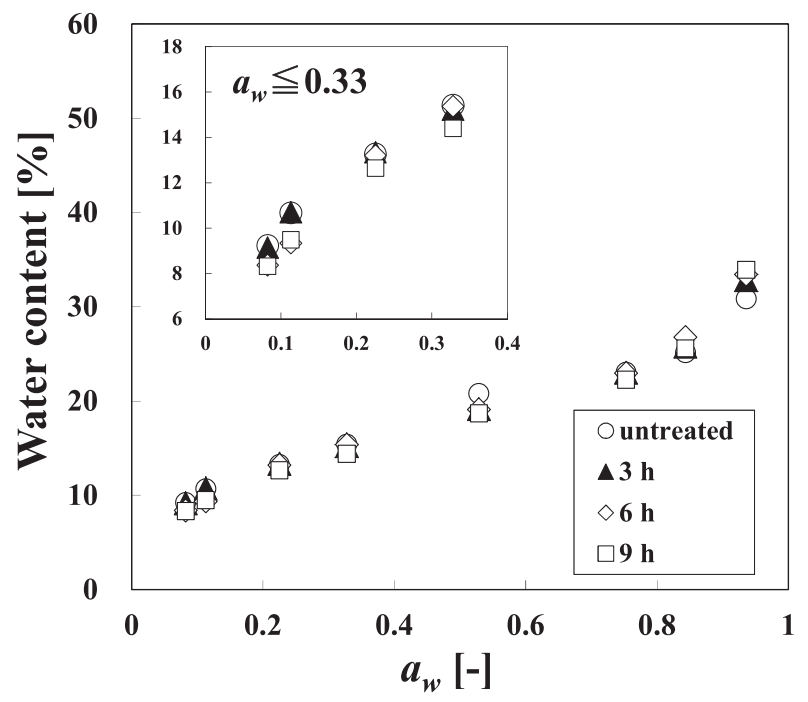

Fig. 3 Water sorption isotherms at $25^{\circ} \mathrm{C}$ for untreated rice flour and ball milled rice flour. 
直線プロットが得られたときの直線プロットの傾きと 切片から $C_{H}^{\prime}$ と $b$ を求めた。 また，解析には， $a_{w} \leqq 0.33$ の水分収着等温線の領域を用いた [22]. Fig. 4 には, その解析結果を示す。その結果，すべての試料におい て $\mathrm{R}^{2}=0.9$ 以上の良好な直線を得ることができ，その直 線プロットの傾きと切片から $C_{H}^{\prime}, \quad b$ を求めることがで きた。

Table. 1 に，このようにして求めた各試料の $C^{\prime}{ }_{H}, b$, $k_{d}$ の值を示す. $C_{H}{ }_{H}$ は，ボールミル処理時間に対し徐々 に減少する傾向を示し, $C^{\prime}{ }_{H}$ の減少はボールミル処理過 程が米粉の吸湿性を低下させることを明確とした。ま た， $k_{d}$ の值をみるとボールミル処理時間が長くなるに つれて増加する傾向を示した。一方で， $b$ の值をみると ばらつく傾向がみられたが，ガスや蒸気分子を収着す る多くの非晶質状高分子系に扎いて，b精度よく求め ることは難しいことが先行研究により指摘されている ことから [39]，本研究において $k_{d}$ と $b$ についての議論 は行わないこととした.

MaCaig らは，ガラス状ポリアリレートフィルムの物 理的エージングを行い，水分透過性について調べてい る $[40,41]$. また, $\operatorname{Kim} ら は 25^{\circ} \mathrm{C} \sim 50^{\circ} \mathrm{C} て ゙$ 物理的エー ジングを施した非晶質澱粉の水分透過性実験で，エー ジング時間が増加するとともに水分透過性が減少する ことを報告しており，澱粉の水分透過性の減少は，工

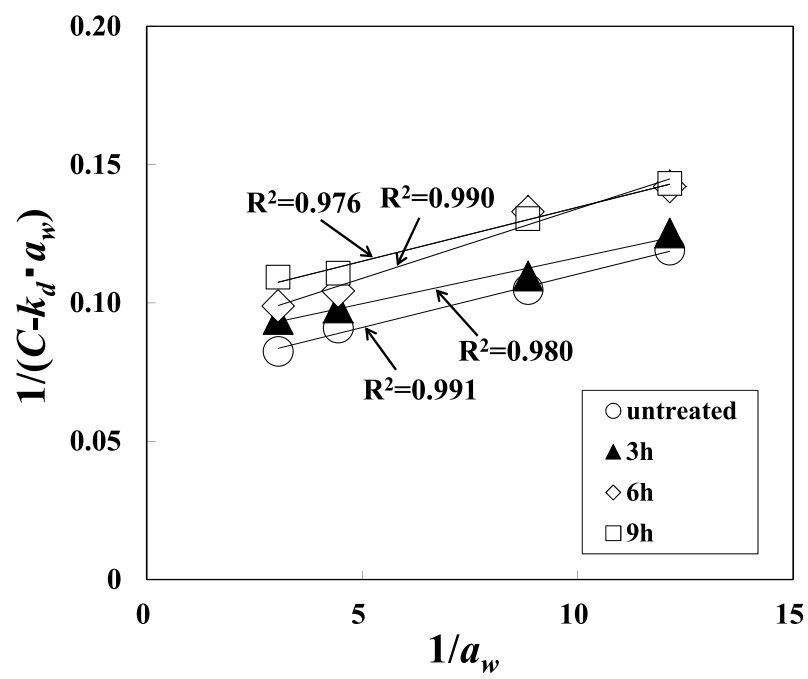

Fig. 4 An example of linearizing plot of Eq. (4) for untreated rice flour and ball milled rice flour.

Table 1 Change of parameters in the dual mode sorption model equation Eq. (4), for ball-milled rice flour.

\begin{tabular}{cccc}
\hline $\begin{array}{c}\text { treating time } \\
{[\mathrm{hr}]}\end{array}$ & $\begin{array}{c}C_{H}^{\prime} \\
{[\%]}\end{array}$ & $\begin{array}{c}b \\
{\left[\mathrm{~atm}^{-1}\right]}\end{array}$ & $\begin{array}{c}k_{d} \\
{\left[\mathrm{~cm}^{3} \mathrm{~g}^{-1}\right]}\end{array}$ \\
\hline 0 & 16.2 & 12.6 & 10.0 \\
3 & 12.7 & 20.7 & 14.0 \\
6 & 11.8 & 17.2 & 16.0 \\
9 & 10.8 & 22.1 & 16.0 \\
\hline
\end{tabular}

ンタルピー緩和の進行に伴い，自由体積が減少したた めだと推論している [42]. 彼らの結論に基づくと，本 研究においてボールミル処理した米粉の $C^{\prime}{ }_{H}$ が減少し たという結果は自由体積の減少のためとも理解するこ とができるが， $C_{H}^{\prime}$ の減少は打そらく水分子によって移 動する水酸基がわずかではあるが水分子と相互作用し 水分が収着する部位を放出するため，ボールミル処理 により $C_{H}{ }_{H}$ が減少するようにみえるのではないかと推 測している [32].

Fig. 5 に，各試料の $C^{\prime}{ }_{H}$ と $\Delta H$ の関係を示す。その結 果，米粉に打いて $\Delta H$ と $C_{H}{ }_{H}$ は直線関係を示した。こ れは，米粉のボールミル処理によるエンタルピー緩和 の増加に伴い水分収着性が低下することを意味し，先 行研究と同様の傾向を示したことから，米粉への適応 も可能となったことが示唆された.

Hachiska らは，ポリビニリデンの物理的エージング 処理を行い，エージング処理時間の増加に伴い非晶化 されたポリビニリデンのペネトラントの水分収着能が 減少したと報告している。彼らは, 非晶質ポリビニリ デンの $\Delta H$ と $\mathrm{CO}_{2}$ 吸着から決定された $C_{H}^{\prime}$ について調 ベ，両者には直線関係がみられることを確認したこと から，ポリビニリデンのペネトラントの水分収着能の 低下は，物理的エージング処理の進行に伴い $\Delta H$ が増 加し，ポリビニリデンの自由体積が減少したためだと 報告している [43]. $\Delta H$ の増加による $C_{H}{ }_{H}$ の減少が非 晶質化した高分子に共通した特徴とすれば，天然高分 子である澱粉が同様の傾向を示したことは，合成高分 子に関した先行研究とは矛盾しないと考える。また， 本研究で得られた $\Delta H$ と $C^{\prime}{ }_{H}$ の間で直線関係がみられ たことから，ボールミル処理米粉の $\Delta H$ の測定から $C_{H}{ }_{H}$ の予測が可能となった.

以上，本研究により，ボールミル処理により米粉の

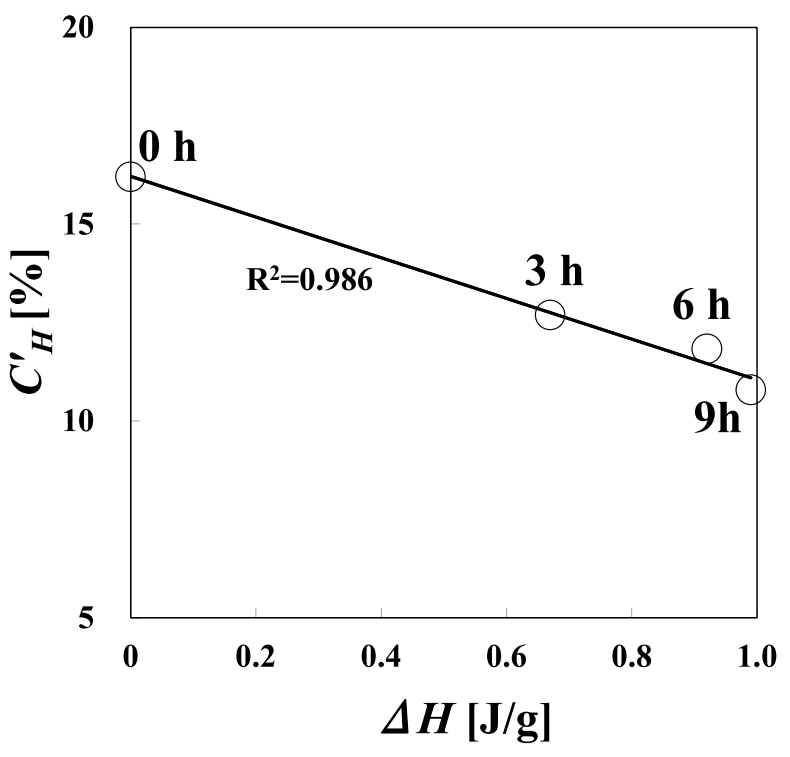

Fig. $5 C_{H}^{\prime}$ vs. $\Delta H$ plot for ball milled rice flour. 
吸湿特性を改善できることを確認したことから，今後新 たな物理化学的特性を有する米粉の作成が期待される.

\section{4. 結論}

未処理米粉に扔いて，X線回折測定で観察された結 晶性を示す回折曲線は，ボールミル処理時間の増加に 伴いピークが消失する傾向を示し，ボールミル処理 9 時間でほぼ完全な非晶質状態を示した。また，米粉の エンタルピー緩和量 $(\Delta H)$ は処理時間の増加とともに 増加する傾向を示した。一方，単分子層収着が飽和し たときの収着量を示す $C^{\prime}{ }_{H}$ は，処理時間に伴い減少傾 向を示した。ささらに，先行研究と同様に， $\Delta H$ と $C_{H}^{\prime}$ に は直線関係がみられることが示唆されたことから，米 粉の $C_{H}{ }_{H}$ の減少は, エンタルピー緩和を導くボールミ 儿処理による物理的处理の結果として得られたものだ と考えられ，米粉への適応が可能なことが示唆された. したがって，本研究により，ボールミル処理が米粉の 吸湿特性を改善させ，ボールミル処理機が大きくなっ ても同様の物理化学的特性を有する米粉を作成できる 可能性が見出された。

\section{引 用 文 献}

1) P. Ngamnikom, S. Songsermpong; The effects of freeze, dry, and wet grinding processes on rice flour properties and their energy consumption, J. Food Eng., 104, 632-638 (2011).

2) E. Arai; "Trends in new rice and rice flour processing technology for expanding rice consumption” (in Japanese) Japan J. Integr. Stud. Diet. Habits, 22, 207-212 (2011).

3) K. Yoza, M. Okabe, J. Shima, "Present state and issues of rice powder utilization: rice bread” (in Japanese), J. Jpn Soc. Food Sci. Tech. 55, 444-454 (2008).

4) T. Fujii, M. Shoji; "The fine structure of rice-starch" (in Japanese), Jap J. Appl. Glycosci. 2, 92-96 (2012).

5) T. Takahashi, M. Miura, S. Kobayashi, "Elucidation of the modified cooking and processing suitability of rice flour by heat treatment" (in Japanese), Bull. Akita Research Inst. of Food and Brewing, 8, 1-6 (2006).

6) T. Takahashi, K. Shinoda, M. Miura, Z. Jin, S. Kobayashi, "Effect of heat treatment on physicochemical properties of rice flour (Utilization for cooking and food processing of heat-treated rice flour part I" (in Japanese), J. Jpn Soc. Food Sci. Tech., 49, 757-764 (2002).

7) T. Yamada, S. Tamaki, S. M. Hisamatsu, K. Teranishi; Molecular change of starch granule with physical treatment potato starch by ball mill treatment. Spec. Publ. R. Soc. Chem., 205, 59-67 (1997).

8) R. Stute, R. W. Klingler, S. Boguslawski, M. N. Eshtiaghi, D.
Knorr; Effect of high pressure treatment on starches, Starch, 48, 399-408 (1996).

9) T. Kuge, S. Kitamura; Annealing of starch granules, Starch Sci., 32, 65-83 (1985)

10) A. Yamamoto, K. Shirakawa; Annealing of long-term stored rice grains improves gelatinization properties, Cereal Chem., 76, 646-649 (1999).

11) S. Hagiwara, K. Esaki, S. Kitamura, T. Kuge; "Observation by photomicroscopic and X-ray Diffraction Method of HeatMoisture Treatment on Starch Granules” (in Japanese), J. Jpn Soc. Starch Sci., 38, 241-247 (1991).

12) L. Sair; Heat-Moisture Treatment of Starch, Cereal Chem., 44, 8-26 (1967).

13) G. Lewandwicz, T. Jankowski, J. Fornal; Effect of microwave radiation on physicochemical properties and structure of cereal starches, Carbohydr. Polym., 42, 193-199 (2000).

14) J. R. Bryant, S. R. Kadan, T. E. Campane,T. B. Vinyard, D. Bpykin; Functional and digestive charcteristics of extruded rice flour, Cereal Chem., 78, 131-137 (2001).

15) M. S. Hossen, I. Sotome, M. Takkenaka, S. Isobe, M Nakajima, N. Shimizu, H. Okadome, Ultra-fine Pulverization of rice: effects on hydration properties and enzymatic hydrolysis, Jpn J. Food. Eng., 14, 37-46 (2013).

16) Y. Okamoto, K. Matsuno, A. Tsumura, S. Terano, "The study of estimating rice flour content in rice bread" (in Japanese), J. Integr. Stud. Diet. Hobits, 22, 41-48 (2011).

17) A. Watanuki, Y. Hara, E. Arai, "Effect of Weakly Electrolyzed Water on the Physical Properties" (in Japanese), Jpn J. Cook Sci., 37, 352-359 (2004).

18) A. Marti, R. Caramanico, G. Bottega, M. A. Pagani; Cooking behavior of rice pasta: Effect of thermal treatments and extrusion conditions, LWT - Food Sci. Tech., 54, 229-235 (2003).

19) S. Cham, Supawadee,P.Suwannaporn; Effect of hydrothermal treatment of rice flour on various rice noodles quality, J. Cereal Sci., 51, 284-291(2010)

20) Y. J. Kim, T. Suzuki, T. Hagiwara, I. Yamaji, R. Takai; Enthalpy relaxation and glass to rubber transition of amorphous potato starch formed by ball-milling. Carbohydr. Polym., 46, 1-6 (2001).

21) Y. J. Kim, T. Suzuki, Y. Matsui, C. Pradistsuwanna, R. Takai; Water sorption for amorphous starch and structural relaxation by ball milling. Jpn J. Food Eng., 2, 121-125 (2001).

22) M. Anzai, T. Hagiwara, M. Watanabe, J. Komiyama, T. Suzuki; Relationship between enthalpy relaxation and water sorption of ball-milled potato starch, J. Food Eng., 104, 43-48, (2011).

23) T. Takahashi, N. Shimizu, K. I. B. Fujiu, "Pulverization of rice by ultracentrifuge cryomilling and microstructure of various pulverized rice” (in Japanese) Jpn J. Food Eng., 14, 59-67 
(2013).

24) M. Anzai, M. Watanabe, T. Suzuki, "Water sorption of corn starch/disaccharide amorphous mixtures and crystallization of disaccharides" (in Japanese), Jpn J. Food. Eng., 14, 59-67 (2013).

25) Morrison, W. R., Tester, R. F.; Properties of damaged starch granules. IV . Composition of ball-milled wheat starches and of fraction obtained on hydration. J. Cereal Sci., 20, 69-77 (1994a).

26) W. R. Morrison, R. F. Tester, M. J. Gidley; Properties of damaged starch granules. II. Crystallinity, molecular order and gelatinization of ball-milled wheat and maize starches. J. Cereal Sci., 19, 209-217 (1994b).

27) S. Tamaki, M. Hisamatsu, K. Teranishi, T. Yamada; Structural Change of Wheat Starch Granule by Ball-mill Treatment, Jpn J. Appl. Glycosci., 44, 505- 513 (1997).

28) R. C. Hoseney; "Phase/State Transitions in Foods: Chemical, Structural and Rheological Changes” M. A. Rao, R. W. Hartel ed. Marcel Dekker, 1998, p. 95.

29) K. Kainuma, D. French; Naegeli amylodextrin and its relationship to starch granule structure. II . Role of water in crystallization of B-starch, Biopolym., 11, 2241-2251 (1972).

30) R. S. Stein, R. E. Rundle; On the nature of the interaction between starch and inodine J. Chem. Phys., 16, 195-207 (1948).

31) A. F. Devi, K. Fibrianto, P. J. Torley, B. Bhandari, B.; Physical properties of cryomilled rice starch, J. Cereal Sci., 49, 278284 (2009).

32) G. Williams, D. C. Watts; Non-symmetrical dielectric Behaviour arising from a simple empirical decay function, Trans. Faraday. Soc., 66, 80-85 (1970).

33) D. Kiburn, J. Claude, T. Schewizer, A. Alam. J. Ubbink; Carbohydrate polymers in amorphous states: an integrated thermodynamic and nanostructural investigation, Biomacromolecules, 6, 864-879 (2005).

34) H. J. Thiewes, P. A. M. Steenken; The glass transition and the sub-Tg endotherm of amorphous and native potato starch at low moisture content, Carbohydr. Polym., 32, 123-130 (1997).

35) Y. Miura, "Thermal analysis on gelatinization and retrogradation of starch” (in Japanese), Bull. of Univ., 53, 79-87 (2003).

36) J. Alder, P. M. Baldwin, C. D. Melia; Starch damage. Part. 2 Type of damage in ball-milled potato starch, upon hydration observed by confocal microscopy. Starch, 46, 252-256 (1994).

37) E. D. Strange, C. I. Onwulata; Effects of particle size on the water sorption properties of cereal fiber, J. Food Qual., 25,
63-73 (2002).

38) J. Komiyama, T. Ijima; Diffusion of monoanionic dyed in Nylon. J. Polym. Sci. Polym. Phys. Ed., 12, 1464-1476 (1974).

39) W. J. Koros, D. R. Paul, G. S. Huvard; Energetics of gas sorption in glassy polymers, Polymer, 20, 956-960 (1979).

40) M. S. MaCaig, D. R. Paul; Effect of UV crosslinking and physical aging on the gas permeability of thin glassy polyarylate film. Polymer, 40, 7209-7225 (1999).

41) M. S. MaCaig, D. R. Paul; Effect of film thickness on the change in gas permeability of a glassy polyarylate aging. Part II . Experimental observations, Polymer, 41, 629-637 (2000).

42) Y. J. Kim, T. Hagiwara, K. Kawai, T. Suzuki, R. Takai; Kinetic process of enthalpy relaxation of glassy starch and effect of physical aging upon its water vapor permeability, Carbohydr. Polym., 53, 289-296 (2003).

43) Hachisuka, H., Tsujita, Y., Takizawa, A., Kinoshita, T.; $\mathrm{CO}_{2}$ sorption properties and enthalpy relaxation in alterating copoly (vinylidene cyanide-vinyl acetate). Polymer, 29, 20502055 (1988)

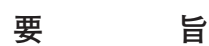

本研究では，ボールミル処理により形成される非晶 質米粉の吸湿性の低下について検討した。ボールミル 処理は，部分結晶状態の澱粉を非晶質状態へと転換さ せ，引き続く処理によりエンタルピー緩和を促進させ ること，澱粉の吸湿性の低下をもたらすことが先行研 究により報告されている。しかしながら，これまでの 先行研究に打いては，澱粉の非晶質化までに打よそ 20 時間を要しており，容器の大きさが小さかったことか ら実生産には向かなかった。

本研究では，先行研究よりも処理量の大きなボール ミル機を用いて米粉を作成した。各試料の結晶性の確 認は, X 線回折測定を用いて行った。また, エンタルピー 緩和量 $(\Delta H)$ を，示差走査型熱量計（DSC）を用いて

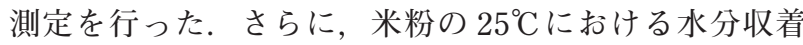
等温線を簡易デシゲータ法にて測定し二元収着モデル 式で解析を行い，これらの各測定から米粉の物理化学 特性を評価した。

その結果, 先行研究と同様に, 米粉のエンタルピー 緩和量はボールミル処理時間の増加とともに増加する 傾向を示し，一方で，単分子層収着が飽和したときの 収着量を示す $C_{H}{ }_{H}$ は，処理時間に伴い低下する傾向を 示したことから，本研究によりボールミル処理は米粉 の吸湿特性を改善させ，ボールミル処理機が大きくなっ ても同様の物理化学的特性を有する米粉を作成できる 可能性が見出された。 